\title{
POLITIK PENYEDERHANAAN SISTEM KEPARTAIAN DI INDONESIA PASCA REFORMASI 1998
}

\author{
Agus Sutisna \\ Universitas Muhammadiyah Tangerang \\ Email: tisna_1965@ymail.com \\ Naskah diterima: 3 Oktober 2015, direvisi: 4 November 2015, disetujui: 9 November 2015
}

\begin{abstract}
Since the 1999 elections electoral democracy Indonesia is marked by drastic changes in the party system implementation, from simple multi-party system in the New Order era to the extreme multiparty system. Judging from the election as the most massive space is provided to facilitate the political participation of the people, multiparty phenomenon is certainly a sign that democracy was growing. But in terms of the need to realize the importance of a stable and effective government, multiparty phenomenon is actually not a wise choice. Scott Mainwaring comparison study results conclude that the application of a multi-party system with a presidential system is a bad combination. That is why since the 2004 elections simplification efforts of party system in Indonesia is done through various policy strategy. This paper is a study about the application of extreme multiparty system and its impact on the election, the behavior of political parties in Parliament, and the relation of Parliament-President; and political strategy or policy simplification of party system that has been taken in Indonesia after the reform to realize a simple multiparty system.
\end{abstract}

Keywords: election; multiparty system; the presidential system; simplifying system policy political parties

\begin{abstract}
Abstrak
Sejak Pemilihan umum 1999 demokrasi elektoral Indonesia ditandai oleh perubahan drastis dalam sistem kepartaian yang diterapkannya, dari sistem multipartai sederhana di era orde baru ke sistem multipartai ekstrim. Dilihat dari sisi pemilihan umum sebagai ruang paling massif yang disediakan untuk memfasilitasi partisipasi politik rakyat, fenomena multipartai ini tentu menjadi isyarat bahwa demokrasi sedang bertumbuh. Tetapi dilihat dari sisi kebutuhan pentingnya mewujudkan suatu pemerintahan yang stabil dan efektif, fenomena multipartai ini sebetulnya bukanlah pilihan yang bijak. Hasil studi perbandingan Scott Mainwaring menyimpulkan bahwa penerapan sistem multipartai dengan sistem presidensial adalah kombinasi yang buruk. Itu sebabnya sejak Pemilihan umum 2004 upaya-upaya penyederhanaan sistem kepartaian di Indonesia dilakukan melalui berbagai strategi kebijakan. Tulisan ini merupakan kajian seputar penerapan sistem multipartai ekstrim dan dampaknya terhadap pelaksanaan pemilihan umum, perilaku partai politik di dalam parlemen, dan relasi parlemen-presiden, dan strategi kebijakan atau politik penyederhanaan sistem kepartaian yang sudah ditempuh di Indonesia pasca reformasi untuk mewujudkan sistem multipartai sederhana.
\end{abstract}

Kata kunci: pemilihan umum; sistem multipartai; sistem presidensial; kebijakan penyederhanaan sistem kepartaian

Pengutipan: Sutisna, A. (2015). Politik Penyederhanaan Sistem Kepartaian di Indonesia Pasca Reformasi 1998. SOSIO DIDAKTIKA: Social Science Education Journal, 2(2), 2015, 167-175. doi:10.15408/sd.v2i2.2816.

Permalink/DOI: http://dx.doi.org/10.15408/sd.v2i2.2816 


\section{A. Pendahuluan}

Setelah berakhirnya pemerintahan Soeharto, yang ditandai dengan masuknya era reformasi dan berakhirnya rezim orde baru pada bulan Mei tahun 1998, memunculkan fenomena ledakan partisipasi politik secara massif pada kehidupan politik Indonesia. Partisipasi politik dari berbagai elemen masyarakat tumbuh dan merebak. Di satu sisi, situasi ini menggambarkan dengan jelas bahwa demokrasi yang sesungguhnya sedang tumbuh dalam masyarakat tetapi di sisi lain bentuk-bentuk ekspresi dan artikulasi partisipasi politik itu juga menjurus ke arah yang destruktif dan berpotensi menimbulkan perpecahan dan disintegrasi bangsa.

Dalam konteks penyelenggaraan pemilihan umum, setelah puluhan tahun dikelola dan dikendalikan dengan cara-cara yang sarat manipulasi serta berbagai pembatasan ruang kebebasan berekspresi dan partisipasi yang bersifat sistemik dibawah rezim orde baru, ledakan partisipasi politik itu tampak dalam pemilihan langsung yang ditandai oleh adanya perubahan sistem kepartaian, dari sistem multipartai sederhana ke sistem multipartai ekstrim. Partai politik tumbuh layaknya jamur di musim hujan. Akibatnya pemilihan umum 1999, pemilihan umum pertama setelah Soeharto lengser, menjadi pemilihan umum yang sangat kompleks dan rumit. Suatu kompleksitas dan kerumitan yang tidak hanya dialami oleh penyelenggara pemilihan umum, tetapi juga dialami oleh para pemilih, terutama para pemilih manula (manusia lanjut usia), pemilih buta aksara, serta pemilih yang pengetahuan politiknya relatif terbatas.

Kompleksitas dan kerumitaan penyelenggaraan pemilihan umum terus berlanjut, karena pemilihan umum 1999 tidak menghasilkan konfigurasi kepartaian yang sederhana di parlemen; sementara pelembagaan pembatasan jumlah partai melalui perundangundangan pemilihan umum untuk pemilihan umum 2004, pemilihan umum 2009 bahkan hingga pemilihan umum 2014 terbukti belum cukup efektif untuk menekan jumlah partai peserta pemilihan umum maupun jumlah partai di parlemen.
Hasil pemilihan umum 2014, jumlah partai di parlemen bertambah 1 (satu) partai. Hasil pemilihan umum 2014 yang mengantarkan 10 partai politik masuk ke dalam parlemen karena lolos dari ambang batas perolehan suara minimal partai politik dalam pemilihan umum untuk diikutkan dalam penentuan perolehan kursi di Dewan Perwakilan Rakyat dan Dewan Perwakilan Rakyat Daerah (parliamentary threshold) ini sekaligus menjadi isyarat, bahwa pemilihan umum 2019 mendatang, masih akan diikuti oleh banyak partai politik. Hal ini didasarkan pada ketentuan Pasal 8 ayat (1) UU Nomor 8 Tahun 2012 tentang Pemilihan umum DPR, DPD dan DPRD yang memastikan, bahwa: "Partai Politik Peserta Pemiliban umum pada Pemilihan umum terakbir yang memenubi ambang batas perolehan suara darijumlah suara sah secara nasional ditetapkan sebagai Partai Politik Peserta Pemilihan umum pada Pemiliban umum berikutnya." Berdasarkan Keputusan KPU Nomor 412/Kpts/KPU/Tahun 2014, kesepuluh partai politik yang lolos parliamentary threshold dan dengan sendirinya berhak menjadi peserta Pemilihan umum 2019 adalah : Partai Hanura (5,26\%), PPP (6,53\%), Partai Nasdem (6,72\%), PKS (6,79\%), PAN (7,59\%), PKB (9,04\%), Partai Demokrat (10,19\%), Partai Gerindra (11,81\%), Partai Golkar (14,75\%), dan PDI Perjuangan (18,95\%).

Di luar kesepuluh partai politik yang lolos parliamentary threshold dan otomatis menjadi peserta Pemilihan umum 2019, sudah barang tentu akan lahir partai-partai baru dan atau partai-partai lama yang tidak lolos parliamentary threshold tetapi kemudian menyesuaikan diri dengan ketentuan perundang-undangan sedemikian rupa sehingga dapat memenuhi syarat kepesertaan Pemilihan umum 2019. Mengenai hal ini, Pasal 8 ayat (2) UU Nomor 8 Tahun 2012 mengatur sebagai berikut :

"Partaipolitikeyang tidak memenubi ambang batas perolehan suara pada Pemiliban umum sebelumnya atau partai politik baru dapat menjadi Peserta Pemiliban umum setelah memenubi persyaratan: (a) berstatus badan bukum sesuai dengan Undang-Undang tentang Partai Politik; (b) memiliki kepengurusan di selurub provinsi; (c) memiliki kepengurusan di 75\% (tujuh puluh lima persen) jumlah kabupaten/kota di provinsi yang bersangkutan; (d) memiliki kepengurusan di 50\% 
(lima puluh persen) jumlah kecamatan di kabupaten/ kota yang bersangkutan; (e) menyertakan sekurangkurangnya 30\% (tiga puluh persen) keterwakilan perempuan pada kepengurusan partai politik tingkat pusat; (f) memiliki anggota sekurang-kurangnya 1.000 (seribu) orang atau 1/1.000 (satu per seribu) dari jumlah Penduduk pada kepengurusan partai politik sebagaimana dimaksud pada buruf c yang dibuktikan dengan kepemilikean kartu tanda anggota; (g) mempunyai kantor tetap untuk. kepengurusan pada tingkatan pusat, provinsi, dan kabupaten/kotasampai tahapan terakbir Pemiliban umum; (b) mengajukan nama, lambang, dan tanda gambar partai politik. kepada KPU; dan (i) menyerabkan nomor rekening dana Kampanye Pemiliban umum atas nama partai politik kepada KPU."

Dengan demikian, berbagai problematika dalam demokrasi elektoral yaitu sebuah sistem konstitutional yang menyelenggarakan pemilihan umum multipartai yang kompetitif dan teratur dengan hak pilih universal untuk memilih anggota legislatif dan eksekutif di Indonesia pada pemilihan umum 2019 dan Pemilihan umum 2024 tampaknya masih akan terus berlanjut, terutama jika kemudian jumlah peserta pemilihan umum 2019 meningkat melebihi angka 15 partai politik; dan partaipartai yang lolos parliamentary threshold pada pemilihan umum 2019 bertambah jumlahnya.

Pemilihan umum dengan sistem multipartai ekstrim yang ditandai oleh jumlah partai politik peserta yang terlalu banyak memang cenderung melahirkan sejumlah problematika dan dampak politik yang tidak sehat dalam kehidupan kepolitikan bangsa. Sebagaimana tampak gejalanya dalam perhelatan pemilihan umum pasca reformasi, problematika itu tampak pada aspek-aspek teknis perencanaan; penganggaran; manajemen logistik (pengadaan dan distribusi); pengaturan kampanye; tatakelola administrasi pelaksanaan pemungutan dan penghitungan suara; bahkan juga pada penyelesaian sengketa dan perselisihan hasil Pemilihan umum di kemudian hari.

Di samping menyangkut aspek teknis penyelenggaraan, pemilihan umum dengan sistem multipartai ekstrim juga berpotensi melahirkan konfigurasi kekuatan politik yang seimbang di parlemen karena sulitnya melahirkan partai pemenang pemilihan umum dengan perolehan suara yang signifikan untuk membentuk pemerintahan. Akibatnya, koalisi harus dibentuk untuk membangun blok-blok kekuatan dalam kerangka penyelenggaraan pemerintahan; dan koalisi yang terbentuk dalam situasi seperti ini cenderung hanya didasarkan pada praktik-praktik transaksional antar partai/ fraksi di parlemen.

Problematika yang tidak kalah penting adalah menyangkut relasi parlemen-pemerintah (DPR-Presiden). Pemilihan umum dengan jumlah partai yang terlalu banyak yang berdampak pada tidak adanya partai pemenang pemilihan umum dengan perolehan suara mayoritas yang signifikan, terlebih lagi jika parlemen justru dikuasai oleh partai atau koalisi partai yang berbeda dengan partai atau koalisi partai yang menjadi pendukung presiden terpilih, cenderung mengakibatkan tidak efektifnya pemerintahan presidensial.

Oleh sebab itu gagasan dan upaya-upaya nyata untuk melakukan penyederhanaan sistem kepartaian dengan memangkas jumlah partai peserta pemilihan umum dan atau partai politik di parlemen sedemikian rupa, sehingga terwujud sistem multipartai sederhana (moderate multiparty system) menjadi penting untuk terus didorong dan dipromosikan dalam kepolitikan Indonesia ke depan.

\section{B. Landasan Teori}

Sistem Kepartaian (party system) untuk pertama kalinya diperkenalkan pada tahun 1950an oleh Maurice Duverger yang melakukan klasifikasisistemkepartaianmenjaditigakategori, yaitu : sistem partai-tunggal, sistem dwi-partai, dan sistem multi-partai. ${ }^{1}$ Para ilmuwan politik menganggap, bahwa istilah "sistem" dalam kosakata "sistem kepartaian" untuk kategori yang pertama (sistem partai-tunggal) adalah contradictio in terminis (menyangkal diri sendiri), sebab suatu sistem lazimnya selalu mengandung lebih dari satu bagian elemen. Dalam bukunya Political Parties, Duverger juga tidak memberikan h. 415

1 Miriam Budiardjo, Dasar-Dasar Ilmu Politike (Jakarta: Gramedia, 2008), 
rumusan pengertian tentang sistem kepartaian, kecuali secara implisit menggambarkannya melalui klasifikasi tadi. Selain itu, Duverger tidak pula menjelaskan bagaimana internal partai mempengaruhi kompetisi dan kerjasama, ideologi partai dan kekuatannya. ${ }^{2}$

Rumusan yang lebih operasional dan menggambarkan "suasana sistem" dari terma "sistem kepartaian" dikemukakan oleh William N. Chamber, yang merumuskan sistem kepartaian sebagai pola interaksi antara dua atau lebih partai politik yang bersaing untuk mendapatkan kekuasaan dalam pemerintahan dan untuk mendapatkan dukungan dari para pemilih, sehingga perilakunya perlu diperhitungkan dalam pemerintahan dan pemilihan umum. ${ }^{3}$

Pengertian yang tidak jauh berbeda dikemukakan oleh Daniele Caramani ${ }^{4}$ yang merumuskan sistem kepartaian sebagai "....are sets of parties that compete and cooperate with the aim of increasing their power in controlling government' (sekumpulan partai yang bersaing dan bekerjasama dengan tujuan meningkatkan kekuasaan mereka dalam mengontrol pemerintahan. Selanjutnya Caramani menjelaskan terdapat 3 (tiga) elemen penting yang membentuk sistem kepartaian, yaitu : (1) partai apa yang termasuk; (2) berapa banyak partai dan berapa besarnya; dan (3) bagaimana perilaku masing-masing partai tersebut.

Meski mendapat banyak kritikan dan sanggahan dari rekan sejawatnya, misalnya Giovanni Sartori, klasifikasi sistem kepartaian Duverger (dalam hal ini menyangkut soal jumlah partai sebagai dasar klasifikasi) tetaplah menjadi titik tolak para ilmuwan politik dalam merumuskan pikiran-pikiran mereka tentang sistem kepartaian di kemudian hari. Blondel (1968), Rokkan (1968) dan Sartori (1976) misalnya, selain memasukkan variabel tambahan (relative size of parties pada Blondel, likelihood of single-party majorities and distribution of minority party strengths pada Rokkan, dan ideological distance

\footnotetext{
2 Luis F. Clemente, Party Systems Stability in Latin Ameirca : A Comparative Study (New York: State of University of New York, 2009), h. 20.

3 William N. Chamber dalam Louis Sandy Maisel dan Mark D. Brewer, Parties and Election in America: The Electoral Process (Maryland: Rowman and Littlefield Publishing Group, 2012), h. 15.

4 Daniele Caramani, Comparative Politic (New York: Oxford University Press, 2008), h. 319.
}

pada Sartori), ketiga ilmuwan ini juga tetap menggunakan variabel numbers of parties (jumlah partai) dalam merumuskan gagasannya tentang klasifikasi sistem kepartaian. ${ }^{5}$

Salah satu catatan kritis Sartori atas klasifikasi Duverger adalah pandangannya, bahwa penggolongan sistem kepartaian bukan sekedar masalah jumlah partai, melainkan jarak ideologi di antara partai-partai yang $\mathrm{ada}^{6}$. Kongkritnya, penggolongan sistem kepartaian didasarkan atas jumlah kutub (polar), jarak di antara kutub-kutub itu (polarisasi) dan arah perilaku politiknya. Berdasarkan dua aspek penting ini : jumlah partai dan jarak ideologinya, Sartori kemudian membuat klasifikasi sistem kepartaian menjadi 4 (empat) tipologi, yaitu : Two-Party Systems (sistem dua partai), Moderate Pluralism (sistem multipartai dengan derajat polarisasi ideologi yang rendah), Polarized Pluralism (sistem multipartai dengan derajat polarisasi yang tinggi), dan Predominant-Party Systems (sistem dimana secara konsisten partai yang sama memenangi mayoritas kursi). ${ }^{7}$

Tipologi yang kedua, Moderate Pluralism menurut Sartori itulah yang kemudian oleh para ilmuwan politik disebut sebagai Moderate Multiparty Systems (Sistem Multipartai Sederhana). Suatu sistem kepartaian yang dicirikan oleh gejala bipolar secara ideologis dengan arah kompetisi yang bersifat sentripetal. Surbakti menjelaskan, yang dimaksud dengan Bipolar ialah kegiatan aktual suatu sistem partai yang bertumpu pada dua kutub, meskipun jumlah partai lebih dari dua karena sistem kepartaian ini tidak memiliki perbedaan ideologi yang tajam. ${ }^{8}$ Atau dalam penjelasan Steven B. Wolinetz dikatakan partai di kedua sisi (kutub) berkompetisi untuk memenangkan suara di tengah dengan 3 (tiga) sampai 5 (lima) partai yang relevan. ${ }^{9}$ Dari sisi jumlah (numbers of parties) untuk Sistem Multipartai Sederhana (moderate multiparty sisytem), para ahli pada umumnya

\footnotetext{
5 Lawrence Leduc, Richard G. Niemi, dan Pippa Norris (eds), Comparing Democracies : Election and Voting in Global Perspective (California: Sage Publication, Inc., 1996), h. 86.

6 Ramlan Surbakti, Memahami Ilmu Politik (Jakarta: Gramedia, 1992), h. 127. Scott P. Mainwarring, Rethinking Party systems in Third Wave of Democratization: The Case of Brazil (California: Stanford Univesity Press, 1999), h. 23 Ramlan Surbakti, Op.cit., h. 127-128.

$9 \quad$ Steven B. Wolinetz, Classiffing Party Systems: Where Have All The Typologies Gone?, Prefared for The Annual Meeting of The Canadian Political Science Association (Monitoba: Memorial University of Newfounland, 2004), h. 6.
} 
menyebut kisaran angka 3 (tiga) sampai 5 (lima) partai yang efektif di parlemen. ${ }^{10}$ Dengan jumlah ini, secara hipotetis konfigurasi kekuatan politik di parlemen akan menjadi sederhana antara partai pemenang pemilihan umum yang memerintah dan partai yang kalah yang akan menjadi oposisi (penyeimbang).

\section{Pembahasan}

\section{Lanskap Sistem Kepartaian di Indonesia Pasca Reformasi 1998}

Setelah puluhan tahun, tepatnya sejak kebijakan restrukturisasi sistem kepartaian yang dilakukan dengan cara fusi (penggabungan, integrasi) "paksa" oleh Soeharto pada tahun 1973, ${ }^{11}$ terhitung mulai pemilihan umum 1999 sistem kepartaian di Indonesia berubah drastis. Sebagaimana dimaklumi, selama 5 (lima) kali berturut-turut sepanjang orde baru (1977, 1982, 1987, 1992, dan 1997) pemilihan umum Indonesia praktis hanya diikuti oleh 2 partai politik dan 1 Golongan Karya. Pemilihan umumnya sendiri berlangsung dalam suasana yang jauh dari fair dan kompetitif, karena kontrol pemerintah yang terlalu jauh ke dalam urusan, baik politik maupun aspek teknis penyelenggaraannya.

Pasca reformasi 1998, pemerintahan transisi dibawah Presiden Habibie kemudian melakukan berbagai perubahan perundangan termasuk di dalamnya Undang Undang yang mengatur tentang partai politik dan pemilihan umum. Dua Undang-Undang penting yang diterbitkan di bawah pemerintah Habibie, yang kemudian menjadi dasar berlakunya sistem multipartai ekstrim dalam Pemilihan umum dan Parlemen Indonesia pasca orde baru adalah Undang-Undang Nomor 2 Tahun 1999 tentang Partai Politik dan Undang-Undang Nomor 3 Tahun 1999 Tentang Pemilihan Umum.

Dengan kedua Undang-Undang inilah pemilihan umum 1999, pemilihan umum pertama di era reformasi digelar. Pemilihan umum 1999 diikuti oleh 48 partai politik peserta pemilihan umum dengan polarisasi ideologi yang sangat beragam. Pelaksanaan pemilihan

\footnotetext{
10 Michael Coppedge, The Dynamic Diversity of Latin America Part Systems, Party Politic, Vol.4 (28 Pebruari 2012), http://cm.olemmis.edu., h. 562. Diakses tanggal 25 Maret 2015; Daniele Caramani, Op.cit., h. 330. 1985), h. 241
}

umumnya sendiri dianggap cukup demokratis dan kompetitif. Hasilnya, 21 partai politik berhasil mengirimkan wakil-wakilnya di DPR RI. Dengan hasil ini, sistem multipartai ekstrim juga mewarnai konfigurasi kekuatan-kekuatan politik di parlemen.

Pada Pemilihan umum berikutnya tahun 2004, jumlah partai politik peserta Pemilihan umum berkurang setengahnya menjadi 24 partai politik. Hal ini dimungkinkan karena muncul ketentuan yang memperberat persyaratan pendirian partai politik sebagai badan hukum dalam partai politik sebagai peserta pemilihan umum. Demikian pula dengan jumlah partai politik di parlemen, meski tidak cukup signifikan, mengalami penurunan jumlah menjadi 17 partai politik; dan 7 diantaranya berhasil lolos dari ambang batas Pemilihan umum (electoral threshold) yang mulai diberlakukan.

Pemilihan umum 2009 jumlah partai politik peserta pemilihan umum kembali melonjak dari angka 24 menjadi 38 partai politik, ditambah dengan partai politik lokal di Aceh sebanyak 6 partai. Dari 38 partai politik tersebut kemudian 9 partai lolos dari ketentuan parliamentary threshold yang mulai diberlakukan menggantikan ketentuan electoral threshold yang dianggap "kurang adil" dan tidak tepat dalam masyarakat yang serba majemuk dan sistem pemilihan umum proporsional seperti di Indonesia.

Pemilihan umum terakhir, tahun 2014, diikuti oleh 12 partai politik peserta pemilihan umum yang berasal dari 9 partai yang lolos PT ditambah 2 partai lama yang berhasil memenuhi ketentuan verifikasi kepesertaan Pemilihan umum 2014. Selain itu, Pemilihan umum 2014 ini juga masih diikuti oleh 3 partai politik lokal di Aceh. Hasilnya, 10 partai politik kemudian lolos parliamentary threshold dan masuk di parlemen, kesepuluh partai ini juga berhak mengikuti pemilihan umum 2019 mendatang; yang dengan demikian, sistem multipartai ekstrim masih akan terus mewarnai kehidupan demokrasi elektoral Indonesia ke depan. 


\section{Politik Penyederhanaan Sistem Kepartaian di Indonesia Pasca Reformasi}

Berangkat dari pelbagai fenomena politik tidak sehat yang diakibatkan oleh penerapan kombinasi sistem multipartai ekstrim dengan sistem presidensial dalam praktik demokrasi elektoral pasca reformasi itu, upaya-upaya berbagai pihak (baik kalangan akademisi, para pegiat pemilihan umum maupun elemen-elemen rasional di tubuh partai politik dan pemerintah) untuk mendorong penyederhanaan sistem kepartaian ke arah sistem multipartai sederhana (moderate multiparty system) menjadi penting dan mendesak untuk terus didukung.

Dalam kaitan upaya penyederhanaan sistem kepartaian ini, beberapa langkah dan strategi kebijakan telah coba diterapkan dalam perhelatan demokrasi elektoral Indonesia sejak Pemilihan umum 2004. Dalam kajian Hadar Gumay dkk, setidaknya ada 5 (lima) jalan yang pernah ditempuh untuk menyederhanakan sistem kepartaian di Indonesia pasca reformasi. (1) Memperberat syarat pendirian partai; (2) Memperberat syarat parpol memperoleh badan hukum; (3) Memperberat syarat parpol untuk ikut Pemilihan umum; (4) Menerapkan ambang batas bagi parpol untuk dapat mengikuti Pemilihan umum berikutnya (electoral threshold); dan (5) Menerapkan ambang batas bagi parpol untuk dapat mengirimkan wakilnya di parlemen (parliament threshold). ${ }^{12}$
Strategi pemberatan syarat pendirian partai politik, syarat memperoleh status badan hukum, dan syarat kepesertaan partai politik dalam pemilihan umum sudah sejak pemilihan umum 2004 diberlakukan melalui UndangUndang Nomor 31 Tahun 2002 tentang Partai Politik dan UU Nomor 12 Tahun 2003 tentang Pemilihan Umum Anggota DPR, DPD dan DPD. Ketentuan pemberatan persyaratan ini terus diberlakukan untuk pemilihan umum 2009 (melalui UU Nomor 2 Tahun 2008 tentang Partai Politik dan UU Nomor 10 Tahun 2008 tentang Pemilihan umum Anggota DPR, DPD dan DPRD), serta untuk Pemilihan umum 2014 (melalui UU Nomor 2 Tahun 2011 tentang Partai Politik dan UU Nomor 8 Tahun 2012 tentang Pemilihan umum Anggota DPR, DPD dan DPRD).

Secara numerik-statistikal, langkah dan strategi kebijakan pengurangan jumlah partai melalui ketentuan perundangan artai politik dan pemilihan umum tersebut memang berhasil menekan jumlah partai politik, baik dalam konteks kepesertaan pemilihan umum maupun di dalam parlemen. Pada tabel 1 menggambarkan dinamika pertumbuhan partai politik sebagai badan hukum yang terdaftar di Depkumham/Kemenkumham, partai politik sebagai peserta pemilihan umum dan partai politik yang berhasil masuk ke dalam parlemen, baik karena memenuhi ambang batas pemilihan umum maupun ambang batas parlemen sejak Pemilihan umum 1999.

Tabel 1. Perkembangan Partai Politik dalam Pemilihan umum dan Parlemen Sejak Pemilihan umum Multipartai Pasca Reformasi

\begin{tabular}{|c|c|c|c|c|}
\hline \multirow[t]{2}{*}{ Kategori } & \multicolumn{4}{|c|}{ Pemilihan Umum } \\
\hline & 1999 & 2004 & 2009 & 2014 \\
\hline Terdaftar di Depkumham & 148 & 112 & 79 & 74 \\
\hline Peserta Pemilihan umum & 48 & 24 & $38+6$ PLA*) & $12+3$ PLA* \\
\hline Partai di Parlemen (DPR RI) & 21 & 17 & 9 & 10 \\
\hline Lolos Electoral Threshold & - & 7 & - & - \\
\hline Lolos Parliament Threshold & - & - & 9 & 10 \\
\hline
\end{tabular}

Diolah dari berbagai sumber

Ket:

*) PLA = Partai Lokal Aceh

12 Hadar Gumay, dkk, Laporan Kajian UU Pemilihan umum, Sebuab Rekomendasi terhadap Revisi UU Nomor 10/2008 tentang Pemiliban umum Anggota DPR, DPRD Provinsi, DPRD Kabupate/Kota dan DPD (Jakarta: Cetro, 2011), h. 25. 
Namun jika dilihat dari segi kebutuhan melahirkan sistem multipartai sederhana dengan kisaran jumlah diantara 3-5 partai politik di parlemen yang secara hipotesis memungkinkan berlangsungnya penyelenggaraan pemerintahan presidensial yang stabil dan efektif, prestasi pengurangan numerikal ini masih jauh dari harapan. Sehingga, implementasi kebijakan penyederhanaan sistem kepartaian yang sudah ditempuh sejak Pemilihan umum 2004 menurut hemat penulis masih gagal dilihat dari segi kebutuhan menghasilkan sistem multipartai sederhana, terutama di dalam parlemen.

Selain melalui strategi kebijakan pemberatan syarat-syarat pendirian, perolehan badan hukum dan kepesertaan partai politik dalam Pemilihan umum, strategi kebijakan penyederhanaan sistem kepartaian di Indonesia juga sudah pernah ditempuh melalui ketentuan electoral threshold yang diberlakukan pada Pemilihan umum 2004, dan ketentuan parliamentary threshold yang mulai diberlakukan pada Pemilihan umum 2009 dan Pemilihan umum 2014 lalu.

Electoral Threshold (ET) atau ambang batas perolehan suara partai politik dalam Pemilihan umum adalah ketentuan yang mengatur tentang batas minimal perolehan suara partai politik dalam pemilihan umum agar partai tersebut dapat mengikuti pemilihan umum berikutnya. Ketentuan ini di dalam Pasal 9 ayat (1) diatur sebagai berikut: "Untuk dapat mengikuti Pemilihan umum berikutnya, Partai Politik Peserta Pemilihan umum, harus : (a) memperoleh sekurang-kurangnya $3 \%$ (tiga persen) jumlah kursi DPR; (b) memperoleh sekurang-kurangnya 4\% (empat persen) jumlah kursi DPRD Provinsi yang tersebar sekurangkurangnya di $1 / 2$ (setengah) jumlah provinsi seluruh Indonesia; atau (c) memperoleh sekurang-kurangnya 4\% (empat persen) jumlah kursi DPRD Kabupaten/Kota yang tersebar di $1 / 2$ (setengah) jumlah kabupaten/kota seluruh Indonesia."

Strategi kebijakan yang terakhir diberlakukan selain melalui pemberatan syaratsyarat pendirian, perolehan badan hukum dan syarat kepesertaan dalam pemilihan umum tadi, adalah kebijakan parliamentary threshold (ambang batas parlemen). Kebijakan ini mulai diberlakukan sejak pemilihan umum 2009 dengan besaran angka 2.5\% dari jumlah suara sah secara nasional (Pasal 202 Undang-Undang Nomor 10 Tahun 2008), kemudian ditingkatkan pada Pemilihan umum 2041 menjadi 3.5\% dari jumlah suara sah secara nasional (UndangUndang Nomor 8 Tahun Tahun 2012 dan Putusan Mahkamah Konstitusi).

Sekali lagi secara numerik, jumlah partai baik dalam pemilihan umum maupun di Parlemen berhasil ditekan sedemikian rupa tetapi untuk kebutuhan mewujudkan sistem multipartai sederhana tampaknya masih jauh dari harapan. Sebagaimana sudah dibahas di depan, hasil pemilihan umum 2014 dan ketentuan perundangan pemilihan umum yang terakhir memastikan, bahwa Pemilihan umum 2019 yang akan datang masih akan diikuti oleh sekurang-kurangnya 10 partai politik yang saat ini duduk di parlemen karena mereka lolos dari jaring parliamentary threshold, dan hampir pasti akan ditambah dengan jumlah partai baru dan partai lama yang tidak lolos parliamentary threshold namun yang kelak dapat menyesuaikan diri dengan ketentuan perundangan.

\section{Penutup}

Pemilihan umum dengan sistem multipartai ekstrim yang diterapkan sejak pemilihan umum 1999 di Indonesia cenderung menimbulkan berbagai problematika, baik dalam kerangka pelaksanaan pemilihan umumnya sendiri maupun dalam konteks pelaksanaan fungsifungsi parlemen dan dalam kerangka relasi Parlemen-Presiden dalam sistem presidensial. Atas dasar kesadaran itu, berbagai langkah dan strategi kebijakan untuk lebih menyederhanakan sistem kepartaian sedemikian rupa, kemudian ditempuh sejak memasuki Pemilihan umum 2004. Idealnya upaya-upaya ini dapat menghasilkan sistem multipartai sederhana (moderate multiparty system).

Langkah dan upaya penyederhanaan sistem kepartaian yang ditempuh sejak pemilihan umum 2004 dilakukan dengan 5 (lima) strategi kebijakan. Pertama, melalui pemberatan syarat pendirian partai politik. Kedua, melalui 
pemberatan syarat partai politik sebagai badan hukum. Ketiga, melalui pemberatan syarat kepesertaan partai politik dalam Pemilihan umum. Keempat, melalui pemberlakuan electoral threshold. Kelima, melalui pemberlakuan parliament threshold. Kelima langkah strategi kebijakan itu berhasil menekan jumlah partai politik sedemikian rupa, baik dalam perhelatan pemilihan umum maupun di parlemen. Tetapi dilihat dari sisi kebutuhan mewujudkan sistem multipartai sederhana yang kompatibel dengan sistem presidensial, pengurangan ini jelas masih jauh dari harapan ideal. Jumlah 10 partai di parlemen sebagai hasil pemilihan umum terakhir 2014 silam masih merupakan jumlah yang terlalu besar, yang berpotensi melahirkan instabilitas dan inefektifitas penyelenggaraan pemerintahan dengan sistem presidensial.

Oleh karena itu, saran dari penelitian ini, masih diperlukannya terobosan-terobosan strategi kebijakan yang lebih assertif, misalnya dengan memperbesar lagi persentasi ambang batas parlemen menjadi minimal 5\% (lima persen) atau dengan memperkecil besaran dan cakupan Daerah Pemilihan (Dapil). Memang secara hipotetis, jalan pintas alamiah yang paling tepat untuk mewujudkan sistem multipartai sederhana adalah dengan mengubah secara seluruh sistem pemilihan umum, dari Proporsional ke Distrik. Tetapi tentu saja, gagasan mengubah sistem pemilihan umum ke sistem mayoritarian ini membutuhkan kajian yang lebih mendalam dan kritis, mengingat struktur masyarakat Indonesia yang majemuk, yang oleh karenanya dianggap tidak kompatibel dengan sistem mayoritarian ini karena sistem ini cenderung mengabaikan prinsip keterwakilan.

\section{E. Daftar Pustaka}

Budiardjo, Miriam. (2008). Dasar-Dasar Ilmu Politik. Jakarta: Gramedia.

Bulkin, Farchan. (1985). Analisis Kekuatan Politik di Indonesia. Jakarta: LP3ES.

Caramani, Daniele. (2008). Comparative Politic. New York: Oxford University Press.
Chamber, William N., dalam Louis Sandy Maisel dan Mark D. Brewer. (2012). Parties and Election in America: The Electoral Process. Maryland: Rowman and Littlefield Publishing Group.

Clemente, Luis F.. (2009). Party Systems Stability in Latin Ameirca: A Comparative Study. New York : State of University of New York.

Coppedge, Michael. (2012). "The Dynamic Diversity of Latin America Party Systems", Party Politic, Vol.4 (28 Pebruari 2012), http://cm.olemmis.edu. Diakses tanggal 25 Maret 2015.

Gumay, Hadar N. (2011). Laporan Kajian UndangUndang Pemiliban umum, Sebuah Rekomendasi terhadap Revisi UU Nomor 10/2008 tentang Pemiliban umum Anggota DPR, DPRD Provinsi, DPRD Kabupate/Kota dan DPD. Jakarta : Cetro.

Leduc, Lawrence, Richard G. Niemi, dan Pippa Norris (eds). (1996). Comparing Democracies: Election and Voting in Global Perspective. California: Sage Publication, Inc.

Linz, Juan dan Arturo Valensuela (eds). (1994). The Failure of Presidential Democracy: The Case of Latin America Jilid 2, Baltimore. MD: The John Hopkins University Pres.

Mainwarring, Scott P. (1993). "Presidentialism, Multipartism, and Democracy : The Difficult Combination". Sage Publication, Comparative Political Studies, Vol. 26 Nomor 21993.

Mainwarring, Scott P. (1999). Rethinking Party systems in Third Wave of Democratization: The Case of Brazil. California: Stanford Univesity Press.

Nurhasim, Moch., Nusa Bhakti, Ikrar. (2009). Sistem Presidensial dan Sosok Presiden Ideal. Jakarta-Yogyakarta: AIPI-Pustaka Pelajar.

Surbakti, Ramlan. (1992). Memahami Ilmu Politik, Jakarta: Gramedia.

dkk. (2011). Membangun Sistem Kepartaian Pluralisme Moderat. Jakarta: Kemitraan bagi Pembaruan Tata Pemerintahan. 
Wolinetz, Steven B. (2004). Classiffing Party Systems: Where Have All The Typologies Gone?, Prefared for The Annual Meeting of The Canadian Political Science Association. Monitoba: Memorial University of Newfounland. 